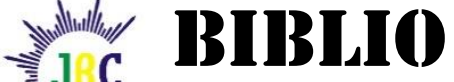 COUNS}

Biblio Couns : Jurnal Kajian Konseling dan Pendidikan

Vol. 2, No. 2, Juli 2019, hlm. 67-71

Tersedia Online di jurnal.umsu.ac.id/index.php/biblio

ISSN 2620-3103 (online)

DOI : https://doi.org/10.30596/bibliocouns.v2i2.3231

\title{
Hubungan Religiusitas dengan Sikap Siswa terhadap Perilaku Prososial
}

\author{
Nurhafiza \\ Program Studi S2 Bimbingan dan Konseling, University Negeri Padang, Sumatera Barat, \\ Indonesia. Korespondensi: Jl. Prof. Hamka, Padang. Email: nurhafiza.fz@gmail.com
}

\section{Article Info}

History of Article

Submited June 2019

Approved July 2019

Published July 2019

\section{Key Word \\ Religiosity, \\ Student Attitude, \\ Prosocial Behavior}

\author{
Kata Kunci \\ Religiusitas, \\ Sikap Siswa, \\ Perilaku Prososial
}

\begin{abstract}
This research is triggered by the depletion of students' prosocial behavior related to how students understand prosocial behavior, what they feel when they see the difficulties of others and what tendencies will arise when they will be prosocial. The purpose of this study was to reveal the relationship between religiosity and student attitudes toward prosocial behavior. This study uses a quantitative approach with a descriptive correlational type. The population was 322 students and a sample of 62 students was selected using the propotionate stratified random sampling technique. The instrument is religiosity and student attitudes towards the scale of prosocial behavior. Data were analyzed by descriptive statistics, simple regression. Based on the results of the study, it can be seen that there is a positive and significant relationship between religiosity and student attitudes toward prosocial behavior. The implications of this research can be made as an assessment of the needs of students to create guidance and counseling service material
\end{abstract}

\begin{abstract}
Abstrak
Penelitian ini dilatarbelakangi karena menipisnya perilaku prososial siswa terkait dengan bagaimana siswa memahami tentang perilaku prososial, apa yang mereka rasakan ketika mereka melihat kesulitan orang lain dan kecenderungan apa yang akan muncul ketika akan bersikap prososial. Tujuan dari penelitian ini adalah untuk mengungkapkan hubungan antara religiusitas dengan sikap siswa terhadap perilaku prososial. Penelitian ini menggunakan pendekatan kuantitatif dengan tipe deskriptif korelasional. Populasi berjumlah 322 orang siswa dan sampel berjumlah 62 orang siswa yang dipilih dengan teknik propotionate stratified random sampling. Instrumennya adalah religiusitas dan sikap siswa terhadap skala perilaku prososial. Data dianalisis dengan statistik deskriptif, regresi sederhana. Berdasarkan hasil penelitian, dapat diketahui bahwa terdapat hubungan yang positif dan signifikan antara religiusitas dengan sikap siswa terhadap perilaku prososial. Implikasi dari penelitian ini dapat dibuat sebagai penilaian kebutuhan siswa untuk menciptakan materi layanan bimbingan dan konseling.
\end{abstract}

\section{Citation Info}

Nurhafiza. (2019). Hubungan Religiusitas dengan Sikap Siswa terhadap Perilaku Prososial. In Biblio Couns: Jurnal Kajian Konseling dan Pendidikan, 2(02), 67-71. 


\section{PENDAHULUAN}

Perilaku prososial mulai menipis dan jarang ditemui. Daniprawiro (2009) mengungkapkan bahwa menipisnya perilaku prososial sebagai bentuk kepedulian moral muncul di masyarakat, baik di kalangan dewasa maupun remaja. Budaya tradisional yang dikenal dengan gotong royong yang dulu menjadi kebanggaan bangsa Indonesia, kini dengan cepat telah berubah menjadi sifat egoistik, individualistik maupun masa bodoh, tidak mau lagi peduli dengan yang terjadi di sekitarnya. Situmorang (2014) memaparkan contoh menipisnya perilaku prososial remaja, terjadi pula di gerbong commuter line, sekalipun di gerbong tertulis permohonan agar pelanggan lain berpartisipasi untuk mengingatkan kepada yang tidak berhak atas tempat duduk prioritas, pada kenyataannya remaja yang duduk di sana tidak peduli dan tetap membiarkan ibu hamil atau nenek tua berdiri.

Penelitian Nufus (2012) menunjukkan rendahnya perilaku prososial santri, ia menemukan bahwa sebagian santri di Pesantren Nurul Ummah Kotagede, Yogyakarta semakin individualis. Beberapa kasus diantaranya adalah RU (20 tahun) yang ketika sakit terpaksa pergi berobat sendiri karena tidak ada teman yang bersedia mengantar ke dokter, kasus lainnya, AZ (16 tahun) mengaku bahwa ia cenderung menolong teman yang satu kamar dengannya., jika ada teman lain yang sakit, terkedang ia tidak mengetahuinya dengan alasan tidak terlalu dekat dengan orang tersebut. Selain itu, Andeli dan Noor (2015) dalam penelitiannya menguji hubungan religiusitas dengan perilaku prososial pada anggota relawan KORS, dan menunjukkan hasil bahwa terdapat 11 orang dari 32 orang anggota KORSA memiliki perilaku prososial yang sedang.

Banyak faktor yang mempengaruhi siswa untuk berperilaku prososial, diantaranya adalah religiusitas atau sikap keberagaaman. Pismawenzi, Jamaidi dan Andini (2015) menjelaskan bahwa religiusitas merupakan suatu aspek penghayatan atau internalisasi dari nilai-nilai ajaran agama oleh individu yang ikut mendasarinya dalam bertingkah laku untuk menjalani kehidupan. Desmita (2009) mengungkapkan bahwa agama merupakan faktor yang juga mempengaruhi perkembangan perilaku prososial seseorang.

Saroglou, Pichon, Trompette, Verschueren dan Dernelle (2005) menjelaskan bahwa sebagian besar teori-teori psikologi menyimpulkan bahwa religiusitas memberikan kontribusi untuk prososial. Selanjutnya, Saroglou (2006) menyimpulkan bahwa semakin seseorang menghargai Tuhan dan agamanya, kecil kecenderungannya untuk bereaksi dengan cara yang agresif ketika menghadapi kemungkinan terjadinya perselisihan di kehidupan sehari-hari dalam hubungan antar pribadi. Selain itu, Ahmed (2009) menunjukkan bahwa siswa yang memiliki religiusitas yang tinggi secara signifikan lebih kooperatif dalam game publik dan secara signifikan lebih murah hati dalam game diktator daripada siswa lainnya. Sehingga dapat disimpulkan bahwa religiusitas memberikan kontribusi terhadap tinggi rendahnya prososial siswa.

Sikap siswa yang menerima untuk berperilaku prososial masih perlu menjadi sorotan penting bagi guru, orangtua, masyarakat bahkan diri siswa itu sendiri yang diharapkan jangan sampai diabaikan tanpa ada pemeliharaan dan pengembangannya, karena akan mengakibatkan menurunnya kondisi perilaku prososial di lingkungan sekolah. Siswa harus siap untuk menjadi pelaku prososial yang aktif, jika tidak, lingkungan juga akan memberikan timbal balik terhadap sikap dan perilaku yang telah ditampilkannya. Sehingga, hal tersebut akan menimbulkan masalah bagi kehidupannya. Masalah tidak akan lepas dari siswa sepanjang proses interaksinya dengan lingkungan. 


\section{METODOLOGI}

Penelitian ini menggunakan pendekatan kuantitatif dengan jenis deskriptif korelasional. Populasi penelitian adalah seluruh siswa SMA Muhammadiyah 4 Babalan yaitu mencakup kelas X, XI dan XII yang terdaftar pada Tahun Ajaran 2016/2017 yang berjumlah 322 orang siswa. Sampel dalam penelitian ini diambil sebanyak 62 orang siswa dengan Teknik penarikan sampel menggunakan teknik proportionate stratified random sampling. Instrumen yang digunakan adalah skala religiusitas, dan sikap siswa terhadap perilaku prososial. Seluruh instrument yang digunakan sudah melalui tahap uji validitas dan reliabilitas.

\section{HASIL PENELITIAN}

\section{Pengujian Persyaratan Analisis Data}

Uji normalitas variabel religiusitas memiliki skor Asyimp. Sig. yaitu 0,714 dan variabel sikap siswa terhadap perilaku prososial sebesar 0,951 . P value ketiga variabel lebih besar dari taraf signifikan yang telah ditetapkan yaitu 0,05 . Artinya data dari ketiga variabel tersebut berdistribusi normal.

\section{PengujianHipotesis}

Tabel 1. Ringkasan Uji Signifikansi Hubungan Religiusitas dan Konformitas Teman Sebaya dengan Sikap Siswa terhadap Perilaku Prososial Secara Sendiri dan Bersama-sama

\begin{tabular}{cccc}
\hline Variabel & F $_{\text {hitung }}$ & $\mathbf{F}_{\text {tabel }}$ & Signifikansi \\
\hline$X_{1}-Y$ & 22,209 & 3,99 & 0,000 \\
\hline
\end{tabular}

Berdasarkan Tabel 4 dapat ditarik kesimpulan penelitian, yaitu terdapat hubungan yang signifikan antara religiusitas dengan sikap siswa terhadap perilaku prososial. Hal ini ditunjukkan oleh Sig. 0.000 lebih kecil dari 0,05 yang berarti bahwa terdapat hubungan yang signifikan antara religiusitas dengan sikap siswa terhadap perilaku prososial.

\section{PEMBAHASAN}

\section{Hubungan Religiusitas dengan Sikap Siswa terhadap Perilaku Prososial}

Hasil penelitian memperlihatkan terdapat hubungan positif dan signifikan antara religiusitas dengan sikap siswa terhadap perilaku prososial. Hasil ini dipeoleh berdasarkan rangkaian analisis data yang menunjukkan bahwa korelasi religiusitas dengan sikap siswa terhadap perilaku prososial sebesar 0.520 . Hasil penelitian ini didukung oleh penelitian Andelia dan Noor (tanpa tahun) mengungkapkan bahwa nilai korelasi religiusitas dengan perilaku prososial sebesar 0,253. Angka korelasi tersebut menjelaskan terdapat hubungan antara religiusitas dan prososial.

Berdasarkan penelitian Stamatoulakis (2013) mengungkapkan bahwa religiusitas berkorelasi positif dengan prososial, dan agama secara sadar dan langsung akan mempengaruhi orang yang religius untuk mengajak orang lain berperilaku prososial. Selain itu, penelitian Haryati (2013) religiusitas memiliki hubungan yang positif dan signifikan dengan perilaku prososial perawat di Rumah Sakit Bunda Surabaya. Berdasarkan hasil penelitian tersebut dapat diartikan religiusitas merupakan salah satu faktor yang berhubungan dengan sikap siswa terhadap perilaku prososial. Besarnya nilai korelasi dari hasil penelitian ini juga menunjukkan bahwa religiusitas bukan merupakan faktor utama yang berhubungan langsung dengan sikap siswa terhadap perilaku prososial. Selanjutnya, juga dapat 
Biblio Couns : Jurnal Kajian Konseling dan Pendidikan | Vol. 2 No. 2 Juli 2019 diartikan dengan semakin tinggi tingkat religiusitas yang dimiliki siswa, maka semakin tinggi pula sikap terhadap perilaku prososial dari siswa tersebut. Sehingga jika religiusitas pada diri siswa tinggi maka siswa akan cenderung memunculkan sikap yang positif dalam kehidupannya.

\section{KESIMPULAN}

Berdasarkan temuan yang diperoleh dalam penelitian ini berdasarkan analisis statistik dan uji hipotesis serta dikaji dan dijabarkan dalam pembahasan, maka dapat disimpulkan bahwa eeligiusitas siswa masih berada pada kategori sedang, yang berarti bahwa penerapan religiusitas siswa seperti melaksanakan sholat wajib maupun sunnat, berpuasa wajib atau sunnat, berdoa, membaca Al-Quran, dan mengikuti agama belum sepenuhnya dilakukan siswa secara konsisten sehingga hal tersebut perlu dilakukan pengembangan dan peningkatan.

\section{DAFTAR RUJUKAN}

Ahmed, A. M. (2009). Are Religious People More Prosocial? A Quasi-Experimental Study with Madrasah Pupils in a Rural Community in India. Journal for the Scientific Study of Religion, 48(2), 368-374.

Andelia, B. \& Noor, H. (tanpa tahun). Hubungan Religiusitas dengan Perilaku Prososial pada Relawan Korsa (Korps Relawan Salman ITB). Jurnal Prosiding Psikologi, ISSN: 2460-6448.

Ayudhia, R. R. \& Kristiana, I. F. (2016). Hubungan antara Hardiness dengan Perilaku Prososial pada Siswa Kelas XI SMA Islam Hidayatullah Semarang. Jurnal Empati, 5(2), 205-210.

Azwar, S. (2011). Sikap Manusia: Teori dan Pengukurannya. Yogyakarta: Pustaka Pelajar.

Daniprawiro, M. (2009). Menipisnya Budaya Tradisional. Gemari. Edisi 96/Tahun IX/Januari 2009, 78-79.

Desmita. (2009). Psikologi Perkembangan. Bandung: Remaja Rosdakarya.

Desmita. (2015). Psikologi Perkembangan Peserta Didik. Bandung: Remaja Rosdakarya.

Eisenberg, N. \& Mussen, P. H. (2003). The Roots of Prosocial Behavior in Children. Cambridge: Cambridge University Press.

Eisenberg, N., Carlo, G., Murphy, B., \& Court, P. (1995). Prosocial Development in Late Adolescence: A Longitudinal Study. Child Development, 66, 1179-1197.

Haryati, T. D. (2013). Kematangan Emosi, Religiusitas, dan Perilaku Prososial Perawat di Rumah Sakit. Jurnal Psikologi Indonesia, 2(2), 162-172. 
Biblio Couns : Jurnal Kajian Konseling dan Pendidikan | Vol. 2 No. 2 Juli 2019

Pismawenzi, Jamaldi, \& Andini, D. S. (2015). Hubungan Religiusitas dengan Ketahanan Mental. Laporan Penelitian. Padang: Lembaga Penelitian dan Penerbitan IAIN Imam Bonjol.

Santrock, J.W.. (2012). Life Span Development: Perkembangan Masa Hidup Jilid 1 Edisi ke-13 (Benedictine Widyasinta \& Novietha I. Sallama, Penerjemah.). Jakarta : Erlangga.

Saroglou, V. (2006). Religion's Role in Prosocial Behavior: Myth or Reality?. Psychology of Religion Newsletter-AP Division 36, 31(2), 1-16.

Saroglou, V., Pichon, I., Trompette, L., Verschueren, M., \& Dernelle, R. (2005). Prosocial Behavioi and Religion: New Evidance Based on Projective Measures and Peer Ratings. Journal for the Scientific Study of Religion, 44, 323-348.

Sears, D. O., Peplau, L. A., \& Taylor, S. E. (2009). Psikologi Sosial Edisi Kedua Belas (Wibowo, Penerjemah.). Jakarta: Kencana Prenada Media Group.

Situmorang, F. M. (2014). Busway dalam Renungan. Diakses tanggal 06 April 2017 di http://fransmateusbah.wordpress.com/2014/01/06/busway-dalam-renungan/.

Stamatoulakis, K. K. (2013). Religiosity and Prosociality. Procedia, Social and Behavioral Sciences, 82, 830-834. 